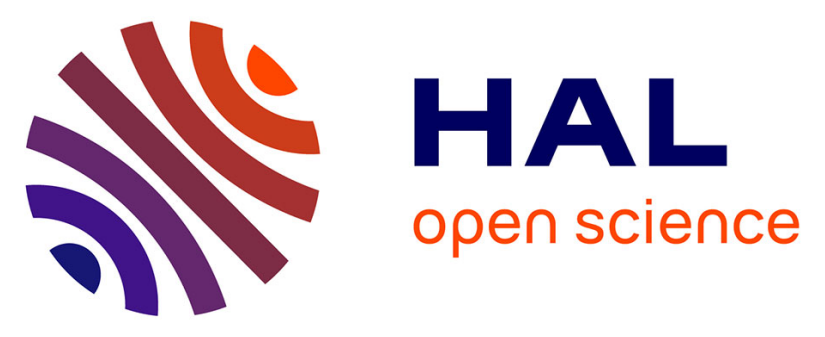

\title{
Spatio-temporal dynamics on a plot scale of cocoa black pod rot caused by Phytophthora megakarya in Cameroon
}

Michel Ndoumbe Nkeng, Mousseni Ives Bruno Efombagn, Lucien Bidzanga Nomo, Ivan Sache, Christian Cilas

\section{To cite this version:}

Michel Ndoumbe Nkeng, Mousseni Ives Bruno Efombagn, Lucien Bidzanga Nomo, Ivan Sache, Christian Cilas. Spatio-temporal dynamics on a plot scale of cocoa black pod rot caused by Phytophthora megakarya in Cameroon. European Journal of Plant Pathology, 2017, 147 (3), pp.579-590. 10.1007/s10658-016-1027-2 . hal-01495104

HAL Id: hal-01495104

https://hal-agroparistech.archives-ouvertes.fr/hal-01495104

Submitted on 31 Oct 2018

HAL is a multi-disciplinary open access archive for the deposit and dissemination of scientific research documents, whether they are published or not. The documents may come from teaching and research institutions in France or abroad, or from public or private research centers.
L'archive ouverte pluridisciplinaire HAL, est destinée au dépôt et à la diffusion de documents scientifiques de niveau recherche, publiés ou non, émanant des établissements d'enseignement et de recherche français ou étrangers, des laboratoires publics ou privés.

$$
\text { Copyright }
$$


2 Relationships between cocoa Phytophthora pot rot disease and climatic

\section{variables in Cameroon}

4 M. Ndoumbè-Nkeng ${ }^{1}$, M.I.B. Efombagn ${ }^{1}$, S .Nyassé ${ }^{1}$, E. Nyemb ${ }^{1}$, I. Sache ${ }^{2}$ and C. Cilas ${ }^{3}$ 5

$6 \quad{ }^{1}$ IRAD, P.O. Box 2123 Yaoundé, Cameroon

$7 \quad{ }^{2}$ INRA, P.O. Box 01, 78850 Thiverval-Grignon, France

$8 \quad{ }^{3}$ CIRAD' Avenue Agropolis, TA A-31/02, 34398 Montpellier Cedex 5, France

9 Corresponding author: Christian Cilas. E-mail: cilas@ cirad.fr Tel: (00 33) 467615609

10

11

12 Relations entre l'incidence de la pourriture des cabosses due à Phytophthora et plusieurs variables climatiques au Cameroun

14 


\section{Abstract}

2 Phytophthora pod rot disease causes almost $30 \%$ loss in world cocoa production.

3 Epidemiological observations showed that the disease appears when there is conjunction

4 between the presence of fruit on trees, whatever their growth stage and when the rainy season

5 has begun. The effects of environment on the epidemic are not well-known in cocoa

6 producing zones. The aim of this study was to assess and quantify the influence of rainfall and

7 temperature on the temporal development of the disease in the cocoa producing areas of

8 Cameroon.

9 The study was conducted in three regions of Cameroon (Mbankomo, Goura and Barombi-

10 Kang). One hundred trees were observed in each site. Disease incidence and crop production

11 data were collected weekly. Rainfall and temperature data were collected daily. Field

12 observations were made over a period of three years (1999-2001). Autocorrelations, cross-

13 correlations and multiple regression analyses were used to establish relationships between

14 disease incidence and the environmental variables.

15 The study showed that pod rot incidence is associated with to rainfall. There is not a univocal

16 relationship established between the two variables. The disease symptoms were expressed one

17 to two weeks after rainfall events. This is a contribution to the creation of a disease warning

18 system to better advise cocoa farmers about disease risk. The present study is, therefore, an

19 important step towards a better understanding of quantitative relations between disease 20 incidence and the environment.

22 Keywords: Cross-correlation; epidemic risk; integrated protection; Phytophthora megakarya; Theobroma cacao. 


\section{Résumé}

2 La pourriture des cabosses du cacaoyer due à divers Phytophthora cause plus de $30 \%$ de

3 pertes de récolte au niveau mondial. Des observations épidémiologiques indiquent que cette

4 maladie apparait lorsque les fruits sont présents sur les arbres, quelque soit leur stade de

5 développement, et lorsque la saison des pluies a débuté. L'influence du climat sur le

6 processus épidémique n'a été, pour le moment, que peu étudiée dans les zones de production.

7 L'objectif de ce travail est de mesurer et de quantifier l'influence des pluies et des 8 températures sur le développement temporel de la maladie dans plusieurs zones de production 9 du Cameroun.

10 Cette étude a été conduite dans trois sites du Cameroun (Mbankomo, Goura et Barombi11 Kang); cent arbres ont été observés par site. Les données concernant la maladie et la 12 production ont été collectées chaque semaine, alors que les variables climatiques ont été collectées tous les jours. Les données ont été recueillies durant trois années consécutives 14 (1999-2001). Des autocorrélations, des corrélations croisées et des régressions multiples ont été utilisées pour mieux comprendre les relations entre l'incidence de la maladie et les facteurs climatiques.

17 Cette étude montre clairement l'incidence de la pluie sur l'intensité de la maladie. Cette incidence se manifeste une ou deux semaines après les pluies. Ce travail jette les bases d'un modèle d'avertissement agricole afin de mieux conseiller les agriculteurs dans la gestion des risques épidémiques. Il s'agit d'une importante étape pour mieux comprendre les relations quantitatives entre l'intensité de la maladie et les variables climatiques.

23 Mots-clés: Corrélations croisées; risque épidémique; protection intégrée; Phytophthora megakarya; Theobroma cacao. 


\section{Introduction}

3 Pod rot, caused by different species of the genus Phytophthora, is widespread in all cacao

4 producing countries. Worldwide, the most common species is $P$. palmivora. In Cameroon, studies revealed the existence of a single species, P. megakarya, that was responsible for the disease (Nyassé, 1992). Although this disease can affect different organs such as the roots or the trunk, it mainly attacks fruits. The different Phytophthora species all cause the same symptoms on pods, namely rotting black patches that sometimes spread to the entire fruit. Damage from

9 pod rot can be up to $30 \%$ of the world harvest every year.

Disease expression in the field is influenced by numerous factors, both environmental and

11 genetic such as environmental conditions (rainfall, wetness and temperature), pathogen survival 12 and dispersal, pathogen species and strain involved, as well as host resistance (Tarjot, 1964; 13 Akrofi et al, 2003; Cilas et al, 2004). All these factors can interact to favour or to restrict disease 14 development. For example, some genotypes of Theobroma cacao may appear resistant in an environment and susceptible in other ones. This phenomenon is known as "genotype $\mathrm{x}$ environment" interaction (Cilas et al., 2004).

The present study focuses on the incidence of environmental factors on dynamics of the disease.

18 Whether in Cote d'Ivoire (Tarjot, 1964, 1967), Ghana (Asare-Nyako, 1973), Cameroon (Muller, 19 1974a, 1974b), Jamaica (Henry, 1977) or Nigeria (Gregory and Maddison, 1981), epidemiological observations showed that Phytophthora pod rot appears when there is a conjunction between the presence of fruit on trees, whatever their growth stage, on one hand and rainy season on the other hand. The effects of climate on the epidemic process are only known in a macroscopic approach in cocoa producing zones (Tarjot, 1964). In Cameroon for example, the 24 incidence of disease tends to be higher in some agro-ecological zones with a mono-modal rainfall regime, compared to those with a bi-modal rainfall regime (Ndoumbè-Nkeng, 2002). 
1 Similarly, a positive correlation has been found between the rate of pod infection and the

2 potential production, implying that the environmental conditions determining both disease 3 incidence and production capacity are similar (Muller, 1974a; Despréaux, 1988). However, this

4 observation does not take into account the climactic variations observed for the whole production

5 period, such as the alternating dry and wet periods and their impact on the process and intensity

6 of the epidemics. Knowledge of the effects of climatic variations on pod rot incidence is useful,

7 particularly to plan fungicide applications.

8 The objective of the study was to assess and quantify the effects of rain events and temperatures

9 on the temporal development of the disease in the cocoa producing areas of Cameroon, like it 10 was done on other crops (Rapilly, 1991). The questions addressed were (1) what are the 11 relationships between climatic factors and disease expression? (2) Is there a threshold for these 12 factors above which the disease occurs?

\section{Materials and Methods}

\section{Study sites and experimental design}

The study was conducted in three locations in Cameroon: Mbankomo (Centre Region, Mefou-et-Akono Division; coordinates: $3^{\circ} 78^{\prime} 0^{\prime \prime} \mathrm{N}$ and $\left.11^{\circ} 38^{\prime} 0^{\prime \prime} \mathrm{E}\right)$, Goura (Centre Region, Mbam-et-Kim Division; coordinates: $4^{\circ} 55^{\prime} 60^{\prime \prime} \mathrm{N}$ and $\left.11^{\circ} 45^{\prime} 0^{\prime}{ }^{\prime} \mathrm{E}\right)$, and Barombi-Kang

21 (South-West Region, Meme Division; coordinates: 4³4'40'’ $\mathrm{N}$ and 9'27’21'’E).

Mbankomo and Goura are situated at altitudes of $730 \mathrm{~m}$ and $480 \mathrm{~m}$, respectively and belong to the agro-ecological zone with a bi-modal rainfall regime, characterised by two dry (from December to February and from June to August) and two wet seasons (from March to May and from September to November). The soils are ferralitic, average (base saturation of 35\%) 
1 to highly (base saturation of $20 \%$ ) unsaturated. Barombi-Kang, altitude $180 \mathrm{~m}$, belongs to an

2 agro-ecological zone with a mono-modal rainfall regime. Barombi-Kang is characterised by a

3 highly humid and hot climate, with a long wet season (March to November) and short dry

4 season (December to February).

5 The sites chosen were thought to be representative of the agro-ecological conditions suitable

6 for optimal cocoa production. On these sites, many farmers were prepared to allow 7 experiments in their cocoa fields. Experimental plots were selected on the basis of 8 accessibility, size and maintenance of the farm. Cocoa plantations studied were about 15 9 years old at Barombi-Kang and Goura and over 25 years of age at Mbankomo. The site at 10 Barombi-Kang had traditional cocoa varieties (Amelonado). There are hybrids cocoa varieties 11 (Amelonado $x$ Trinitario) at Mbankomo and mixed traditional and hybrids varieties at Goura.

12 At each of the three plots, 100 trees were randomly distributed. The plot was surrounded with a phytosanitary barrier made up of two rows of cocoa trees, to prevent chemical treatments and pathogen spread from neighbouring farms. For the purpose of field observations, the observed trees were divided into three levels: $0-0.5 \mathrm{~m}$ (level 1), 0.5-1.50 m (level 2) and > $1.50 \mathrm{~m}$ (level 3). Inside the same plantation, the spacing among trees varied from $2.5 \times 2.5 \mathrm{~m}$ to $3 \mathrm{x} 3 \mathrm{~m}$, corresponding to tree densities of 1111 to 1600 cocoa trees ha ${ }^{-1}$.

\section{Data collection}

21 Rotten pods (caused by Phytophthora sp., ROT), wilted fruit (early desiccation, WILT), fruit 22 damaged by rodents (DAM), fruit infected by diseases other than Phytophthora pod rot (OD), cherelles (fruit $\leq 4 \mathrm{~cm}$ length, $C H E R$ ), young pods (fruit $>4 \mathrm{~cm}$ length but not yet at adult stage, $Y P$ ), adult pods (but not yet mature, $A P$ ), and healthy mature pods $(M P)$ were counted 
1 weekly. These variables were chosen for weekly estimation of pod rot rate (Number of rotten

2 pods / Number of all the pods).

3 At each site, a rain gauge (high: $150 \mathrm{~mm}$ ) was installed in an open area and two thermometers

4 were placed outside the plantation and under the cocoa tree canopy within the plantation,

5 respectively. Rainfall $(\mathrm{mm})$ and temperature $\left({ }^{\circ} \mathrm{C}\right)$ data were collected daily.

6 Observations were made over a period of three years (1999-2001). Disease status and

7 production data were collected weekly from mid-April, when the first pods appeared on the 8 trees, to the end of the production season (mid-November) each year. In total, there were

9 around 30 weeks of data collection per site and per year. After each round of observation, 10 rotten or wilted fruit, as well as fruits damaged by rodents and other diseases were harvested 11 from trees and removed from the farms.

12

13 Based on the data collected, the pod rot incidence $(P R R)$, mean temperature and total rainfall 14 were calculated from the variables measured in the field.

15 The calculation method for the weekly pod rot incidence $(P R R)$, was adapted from the formula used by Berry and Cilas (1994b) and De Jesus (1992). The losses due to PRR were estimated using the potential production:

where

$P R R i=\quad$ Pod rot rate at the week $i$

$$
P R R i=\frac{R O T i}{(R O T i+M P i)} * 100
$$

The minimum surrounding temperatures (SMinT) and those under the cocoa trees canopy 
1 respectively, the averages of minimal and maximal temperatures of the week ( 7 days). The

2 mean temperatures (SMeanT, UCMeanT) are the averages of both weekly minimum and

3 maximum temperatures. The daily thermal amplitude (Amp) was calculated, by taking the

4 difference between maximum and minimum daily temperatures.

5 Similarly, total rainfall per week $(R A I N)$ was the cumulative rainfall calculated from the daily 6 rainfall.

7

8

9

For each derived variable, an analysis of variance (ANOVA) was done per site and per year. The data for three years were pooled to test the site and year effects. Logarithmic or angular transformations were sometimes necessary, to meet the requirements of the general linear model, particularly the homogeneity of variances.

When the test associated to the ANOVAs (F-test) lead to rejection of the null hypothesis, the means were compared by contrasts (Gomez and Gomez, 1984; Tomassone et al., 1993).

Set of variables measured each year for 30 successive weeks $(T)$, could be seen as chronological series, with week as the lag period unit, meaning that the sequence of measurements did not follow a random order. Auto-correlations of variables were estimated with the purpose of understanding disease progress over time, the autocorrelation being defined as the correlation calculated between a series and a lagged version of itself. If the correlation coefficient is calculated for all lags $\mathrm{k}=0,1,2 \ldots \mathrm{N}-1$ the resulting series is called the autocorrelation series or the correlogram. Cross-correlations were calculated for different lags to identify the lag which allows to maximise the correlation between rainfall and PRR incidence, i.e. to determine the number of weeks between rainfall and disease expression. 
1 The autocorrelation coefficient $\rho$, of lag (or period) $k$ was calculated, considering the $T-1$

2 pairs of observations $\left(y_{1}, y_{2}\right),\left(y_{2}, y_{3}\right), \ldots,\left(y_{T-1}, y_{T}\right)$, in the following manner (Box and Jenkins,

31976 ; Tomassone et al., 1993 ; Bourbonnais, 2000) :

4

$$
\rho_{k}=\frac{\sum_{t=1}^{T-k}\left(y_{t}-\bar{y}\right)\left(y_{t+k}-\bar{y}\right)}{\sum_{t=1}^{T}\left(y_{t}-\bar{y}\right)^{2}}
$$

$7 \bar{y}$ represents the mean of the series.

8 All auto-correlation coefficients $\left(\rho_{k}\right)$ were calculated with a lag $k$ - k varying from 1 to 4 9 weeks (Bourbonnais, 2000; Quenouille, 1949; Ljung and Box ,1978).

11 Cross-correlations were computed to evaluate the link between pod rot rate and the environmental variables. The cross-correlation $r$ of $k$ 's lag between two series $x_{i}$ and $y_{i}$ is defined as follows (Bourke, 1996):

14

$$
r_{k}=\frac{\sum_{i}\left(x_{i}-\bar{x}\right)\left(y_{i-k}-\bar{y}\right)}{\sqrt{\sum_{i}\left(x_{i}-\bar{x}\right)^{2}} \sqrt{\sum_{i}\left(\left(y_{i-k}-\bar{y}\right)^{2}\right.}}
$$

Where $i=0,1,2, \ldots T-1$ in week; $\bar{x}$ represents the mean of a series $x_{i}$ and $\bar{y}$ is the mean of the series $y_{i}$. Multiple regression analysis was done to find the most parsimonious model to predict pod rot rate. In order to suppress the auto-correlation present in the series relative to disease incidence $(P R R)$, the difference between two time points was used for the analysis (Kendall, 1976). An angular transformation of the variable $P R R$ (Arcsine $\sqrt{P R R}$ ) was used to ensure the homogeneity of variance which is a requirement of general linear model (Draper and Smith, 1981). 
1 These analyses were carried out per site and per year and subsequently per site with combined

2 the data of the three years. Data were analysed using Statistica and SAS (SAS, 2001), with 3 REG and GLM procedures.

\section{$5 \quad$ Results}

6 The evolution of temperature, quantity of rainfall, and PRR incidence was monitored during 7 three years (Figures 1 to 3). Temperature is not presented because it was more or less constant 8 within each site and within each of the three years.

\section{Temperature and rainfall}

In Mbankomo, 2001 was cooler than 1999 and $2000(P<0.05)$. The reverse was observed in Goura where 2001 was warmer than the two previous years. In Barombi-Kang annual temperatures were not significantly different $(\mathrm{P}>0.05)$ between years (Table 1$)$. At the three sites, annual rainfall (in $\mathrm{mm}$ ) varied among years. In Mbankomo and Barombi-Kang, significant differences $(\mathrm{P}<0.01)$ in rainfall observed in 1999 and 2000 was observed. In addition, the year 2001 was the wettest in these two locations. In Goura, rainfall varied significantly during the three years $(\mathrm{P}<0.001)$ (Table 1$)$. Mbankomo was the site where the lowest temperatures were recorded for all years. The temperatures at Goura and BarombiKang were similar. Barombi-Kang was the site that had the greatest total quantity of rainfall during the three years, and Goura had the lowest, with rainfall below seasonal norms in 2001. Difference of temperature and rainfall means between Mbankomo and Goura (though situated in the same agro-ecological zone) was the outstanding point in the observation of environmental variables. 


\section{Production and Phytophthora pod rot rate}

2

3 The number of healthy pods per tree, for each site and each year is shown in Table 2: in

4 Goura in 2000 (21.31 fruit/tree), in Barombi-Kang in 1999 (21.9 fruit/tree) and in 2000 (19

5 fruit/tree). This was a high number of healthy pods per tree as compared to the average

6 national production of 10 fruit/tree.

7 In each site, pod rot incidence (PRR) was significantly different of over the three years $8 \quad(\mathrm{P}<0.01)$. The highest and the lowest rates were recorded in 2001 in Barombi-Kang and in

9 Goura, respectively (Table 2). For each year, the pod rot incidence (PRR) was significantly 10 different between sites $(\mathrm{P}<0.05)$; Goura was significantly less attacked by pot rot disease than 11 the others sites.

\section{Temporal analysis}

14

The results of simple auto-correlation of rainfall at the three sites during the three years are shown in Table 3. The correlations were very low $(\mathrm{P}>0.05)$. This is characteristic of a white noise process, meaning that the successive rainfall events were not dependant. Conversely, observations of the data presented in Table 4 (auto-correlations of PRR) showed that the successive pot rot rate were dependant, with a significant autocorrelation $(\mathrm{P}<0.05)$. Overall the values of autocorrelation decreased progressively when the lag increased. So, there was a null risk to reject wrongly the hypothesis of nullity of $\rho_{k}$ coefficients; this indicates that the series is not a white noise process, with dependence between successive pod rot rates.

The cross-correlation method allowed for identification of important environmental variables (and associated lags) that affect PRR. Figures 4 to 6 represent cross-correlations coefficients 
1 between PRR and the rainfall. During rain, the disease did not produce symptoms

2 immediately. Overall, the highest significant correlations were obtained with a week lag time

$3 \quad(\mathrm{P}<0.05)$. This result suggests a latent period of one week for the expression of the disease.

4 Cross-correlations results of year 2001 in Goura were not presented, because of the low level 5 of Phytophthora pod rot at the experimental plantation observed during this season.

9 The best results determined by model selection $\left(R^{2}\right)$ were obtained with the step-by-step method. Among all the environmental variables, only RAIN (with one week lag) contributed significantly to the PRR incidence. Table 4 presents the results of regressions that described PRR incidence as a function of quantity of rainfall per site and per year and subsequently per site using the pooled data from the three years. In Goura, only data from 1999 and 2000 were pooled, as pod rot rate was almost zero in 2001. These results always showed that quantity of rainfall had a highly significant effect on PRR incidence. However, the coefficients of determination $\left(R^{2}\right)$, representing the percentage of variability explained by the model, were relatively low for the analysis done per year and per site. The $\mathrm{R}^{2}$ were improved when the data of different years were pooled for each site.

From equations presented in Table 5, the quantity of rainfall can be used to predict PRR

21 incidence at a cocoa farm. For example, it was observed that to reach a weekly pod rot rate of $221 \%$, more rainfall was needed in Mbankomo (48 $\mathrm{mm})$ than in Goura (39 $\mathrm{mm})$ (Table 6).

\section{Discussion}


1 One of the objectives of this study was to establish the relationships between Phytophthora

2 pod rot and two environmental factors. The results clearly showed that disease increased with 3 increasing quantity of rainfall . The highest PRR incidence occurred in 2003 at the Barombi-

4 Kang (70.3\%) and Mbankomo (64.76\%) sites when quantity of rainfall was very high (> 2200

$5 \mathrm{~mm})$. In contrast, the lowest losses were obtained in Goura in $2001(1.15 \%)$ when rainfall was

6 low $(751 \mathrm{~mm})$. However, in this case, the production of healthy pods per tree was also low,

7 probably meaning that the rainfall was not sufficient to induce good fructification. It is

8 generally indicated that a minimum of $1000-1200 \mathrm{~mm}$ of rainfall is required in a cocoa

9 plantation to get a good yield (Mossu, 1990). The best cacao yield is obtained with an

10 intermediate rainfall regime $(1100-2000 \mathrm{~mm})$.

12 To better understand the effects of environmental conditions on disease development, two types of analyses were done: cross-correlation analysis and multiple regression analysis. Results of the cross-correlation analysis showed that there was a lag of one or two weeks between rainfall and disease expression. This may be the result of a incubation period, which is the period from fruit infection and the first disease symptoms. In the case of Phytophthora megakarya, this period lasts six days in cocoa trees (Ward et al., 1981). From the multiple regression analysis, it was possible to determine that the rainfall regime was the best indicator of PRR incidence which allows to better disease prediction. Among the different sites, mean temperature variations, which were relatively constant over the year did not influence the 21 development of the epidemic.

These results are in agreement with those reported by Ward et al. (1981). These authors attempted to model disease development in the field by taking into account the change in the number of total pods per tree over time, the latency period (p) and the duration of active 
1 sporulation zone on each fruit (i). Considering $(p)=6$ days and $(i)=15$ days, the authors

2 discovered that disease incidence on day (d) was correlated to the cumulative number of

3 healthy pods on day (d), to rainfall on day (d-3) and to the cumulative duration of sporulation

4 on pod on day (d-5).

5

6 The long term objective of this study was to contribute to the elaboration of disease

7 forecasting models for cocoa. For this pupose we need to apprehend a great environmental

8 variation and it will be then necessary to collect data over many years

9

\section{Acknowledgments}

13

14 Financial assistance from the FAC project (Fond d'Aide et de Coopération), set up by the

15 French Ministry of Cooperation and the Government of Cameroon, is acknowledged. Sincere 16 thanks are expressed to the staff of the Plant Pathology Laboratory at the Institute of 17 Agricultural Research for Development, Cameroon (E. Bouambi, N. Bindzi, Late T. Simo, N. 18 Essomo), who carried out the field trials. The authors also thank their colleagues (A. Kameni and M. Hoopen) who critically reviewed the manuscript. 


\section{$1 \quad$ References}

Akrofi, A. Y., Appiah A. A., and Opoku, I. Y. 2003. Management of Phytophthora pod rot disease in cocoa farms in Ghana. Crop Protection 22: 469 - 477.

Ambassa-Kiki R. Normales des pluies au Cameroun (1941 - 1970). Personal communicatbion.

Asare-Nyako, A. 1973. Sources of primary field inoculum of Phytophthora palmivora in Ghana. Annual report of the Cocoa Research Institute of Ghana 1970 - 1971. 66 p.

Berry, D., and Cilas, C. 1994. Etude génétique de la réaction à la pourriture brune des cabosses chez des cacaoyers (Theobroma cacao L) issus d'un plan de croisements diallèle. Agronomie, 14 : 599-609.

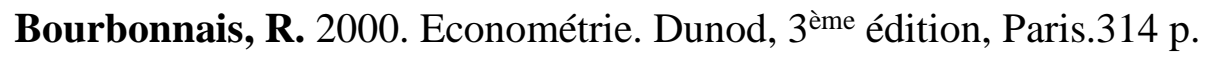

Bourke, P. 1996. Cross correlation. Available from http:// astronomy.swin.edu.au// pbourke/analysis/ (cited April 2002).

Box, G.E., and Jenkins, G. 1976. Time series analysis. Forcasting and control. Holden-Day.

Brasier, C.M., and Griffin, M.J. 1979. Taxonomy of Phytophthora palmivora on cocoa. Trans. Br. Mycol. Soc. 72 : 111-43.

Cilas, C., Ndoumbè-Nkeng, M., Bidzanga-Nomo, and Ngoran J. 2004. Disease incidence and field resistance. In: Improvement of cocoa tree resistance to Phytophthora diseases. Ed: C. Cilas et D. Despréaux. Repères, CIRAD: 77-102.

De Jesus, A.M. 1992. Exploitation des résultats de l'étude «épidémiologie » sur la pourriture brune. Course report, CIRAD-CP, Montpellier.

Despréaux, D. 1988. Etude de la pourriture brune des cabosses du cacaoyer au Cameroun. Deuxième partie: contribution à l'étude de la maladie, groupe de recherche sur les maladies à Phytophthora sp. du cacaoyer. Rapport interne ; IRAD, Yaoundé, Cameroun. 
1 Dodd, J.C., Estrada, A.B., Matcham, J., and Jeffrries, P. 1991. The effect of climatic factors on Colletotrichum gloeosporioides, causal agent of mango anthracnose, in the Philippines. Plant Pathology: 40: 568-575.

Draper, N., and Smith, H. 1981. Applied regression analysis. $2^{\text {nd }}$ edition. John Wiley \& Sons. 709 p.

Gomez, K.A., and Gomez, A. 1984. Statistical procedures for agricultural research $2^{\text {nd }}$ edition. John Wiley \& Sons. 680 p.

Gregory, P.H., and Maddison, A.C. 1981. Epidemiology of Phytophthora on cocoa in Nigeria. Phytopathological Paper n²5, 188 p., Kew, CMI, England.

Henry, C.E. 1977. Primary sources of Phytophthora palmivora (Butl.) Butl. Inoculum in Jamaica and methods of control. $5^{\text {th }}$ International Cocoa Research Conference, Ibadan, Nigeria, 388-396.

Kendall, M. 1976. Time-series. Charles Griffin \& Co. Ltd. 197 p.

Ljung, G.M., and Box, G.E.P. 1978. On a measure of lack of fit in time series model. Biometrika, 65.

Mossu, G. 1990. Le cacaoyer. Maisonneuve \& Larose, Paris. 160 p.

Muller, R.A. 1974a. Effect of prophylactic measures of the disseminationof Phytophthora palmivora. In: Phytophtora Disease of Cocoa (PH Gregory, ed), Longman, London, United Kingdom, 169-178.

Muller, R.A. 1974b. Integrated control methods. In: Phytophtora Disease of Cocoa (PH Gregory, ed), Longman, London, United Kingdom, 259-268.

Ndoumbè-Nkeng, M. 2002. Incidence des facteurs agro-écologiques sur l'épidémiologie de la pourriture brune des fruits du cacaoyer au Cameroun: contribution à la mise en place d'un modèle d'avertissements agricoles. Thèse de Doctorat. INA P-G, Paris, France. 151 pages. 
1 Ndoumbè-Nkeng, M., Cilas, C., Nyemb, E., Nyassé, S., Bieysse, D., Flori, A., and Sache,

I. 2004. Impact of removing diseased pods on cocoa Phytophthora pod rot caused by Phytophthora megakarya and on cocoa production in Cameroon. Crop Protection 23: 415 $-424$.

Nyassé, S. 1997. Etude de la diversité de Phytophthora megakarya et caractérisation de la résistance du cacaoyer (Theobroma cacao L.) à cet agent. Thèse de Doctorat, Inst. Nat. Polytechn. de Toulouse. 133 p.

Quenouille, M.H. 1949. The joint distribution of serial correlation coefficients. Annual Review of Mathematical Statistics, 20.

Rapilly, F. 1991. L'épidémiologie en pathologie végétale. Mycoses aériennes. INRA, Paris. $317 \mathrm{p}$.

SAS Institute Inc. 2001. SAS User's Guide: Statistics. Institute Inc. Release 8.2, Cary, NC, USA

Tarjot, M. 1964. De quelques facteurs favorisant le développement des pourritures de cabosse du cacaoyer en Côte d'Ivoire. Café Cacao Thé. 8(1) : 32-38.

Tarjot, M. 1967 - Etude de la pourriture des cabosses due au Phytophthora palmivora (Butl.) Butl. en Côte d'Ivoire. Lieux de conservation du parasite pendant la saison sèche. Café Cacao Thé 11(4) : 321-330.

Tomassone, R., Dervin, C., and Masson, J.-P. 1993. Biométrie. Modélisation des phénomènes biologiques. Masson, Paris. 553 p.

Ward, M.R., Maddison, A.D., and Adebayo, A.A. 1981. The epidemy on sprayed cocoa at Gambary. In: Epidemiology of Phytophthora on Nigeria. Phytopathological paper No. 25, CMI, p. 145-162. 
1 Table 1: $\quad$ Mean temperatures and rainfall in each site (April - November 1999, 2000, 2001)

\begin{tabular}{|c|c|c|c|c|c|c|c|c|}
\hline \multirow{2}{*}{ Sites } & \multirow{2}{*}{ Year } & \multicolumn{3}{|c|}{ Surrounding temperature $\left({ }^{\circ} \mathrm{C}\right)$} & \multicolumn{3}{|c|}{ Under cocoa trees temperature $\left({ }^{\circ} \mathrm{C}\right)$} & \multirow{2}{*}{ Rainfall (mm) } \\
\hline & & SMinT & SMaxT & SMeanT & UCMinT & UCMaxT & UCMeanT & \\
\hline & 1999 & $\dagger 19.44 \pm 0.18 a$ & $22.10 \pm 0.23 b$ & $20.77 \pm 0.20 a b$ & $18.21 \pm 0.18 a$ & $21.16 \pm 0.16 a$ & $19.69 \pm 0.17 a$ & $1762 \pm 15.02 b$ \\
\hline Mbanko- & 2000 & $19.24 \pm 0.23 a$ & $23.78 \pm 0.29 a$ & $21.51 \pm 0.21 a$ & $18.54 \pm 0.11 a$ & $20.95 \pm 0.27 a b$ & $19.74 \pm 0.21 a$ & $1823 \pm 42.45 b$ \\
\hline \multirow[t]{2}{*}{ mo } & 2001 & $18.35 \pm 0.11 b$ & $21.67 \pm 0.34 b$ & $20.01 \pm 0.18 b$ & $17.29 \pm 0.29 b$ & $20.23 \pm 0.28 b$ & $18.77 \pm 0.20 b$ & $2288 \pm 13.5 a$ \\
\hline & 1999 & $21.16 \pm 0.13 b$ & $31.93 \pm 0.23 b$ & $26.54 \pm 0.14 b$ & $20.08 \pm 0.13 a$ & $28.25 \pm 0.25 b$ & $24.16 \pm 0.15 a$ & $1600 \pm 8.62 a$ \\
\hline \multirow[t]{2}{*}{ Goura } & 2000 & $21.88 \pm 0.15 a b$ & $31.86 \pm 0.16 b$ & $26.87 \pm 1.02 b$ & $20.03 \pm 0.25 a$ & $30.24 \pm 0.14 a$ & $25.14 \pm 0.16 a$ & $1139 \pm 1.50 b$ \\
\hline & 2001 & $22.59 \pm 0.11 a$ & $34.59 \pm 0.48 a$ & $28.59 \pm 0.23 a$ & $21.02 \pm 0.12 a$ & $27.79 \pm 0.24 b$ & $24.40 \pm 0.17 a$ & $751 \pm 3.87 c$ \\
\hline Barombi & 1999 & $22.67 \pm 0.11 a$ & $23.61 \pm 0.20 a$ & $23.14 \pm 0.12 a$ & $21.65 \pm 0.09 a$ & $22.09 \pm 0.20 a$ & $21.87 \pm 0.11 a$ & $2003 \pm 13.80 b$ \\
\hline - & 2000 & $22.49 \pm 0.14 a$ & $23.54 \pm 0.12 a$ & $23.02 \pm 0.12 a$ & $20.64 \pm 0.10 a$ & $22.51 \pm 0.27 a$ & $21.56 \pm 0.14 a$ & $1960 \pm 11.83 b$ \\
\hline Kang & 2001 & $22.11 \pm 0.11 a$ & $23.76 \pm 0.11 a$ & $22.94 \pm 0.09 a$ & $20.83 \pm 0.11 a$ & $22.75 \pm 0.28 a$ & $21.79 \pm 0.18 a$ & $2873 \pm 9.29 a$ \\
\hline
\end{tabular}

$2 \uparrow$ Values are means \pm standard error

3 For each variable at a given site, values followed by the same letter are not significantly different with Newman-Keuls test at 5\% level

4

5

6

7

8

9 Table 2: $\quad$ Mean pod rot rate and production in each site (April - November 1999, 2000, 2001) 


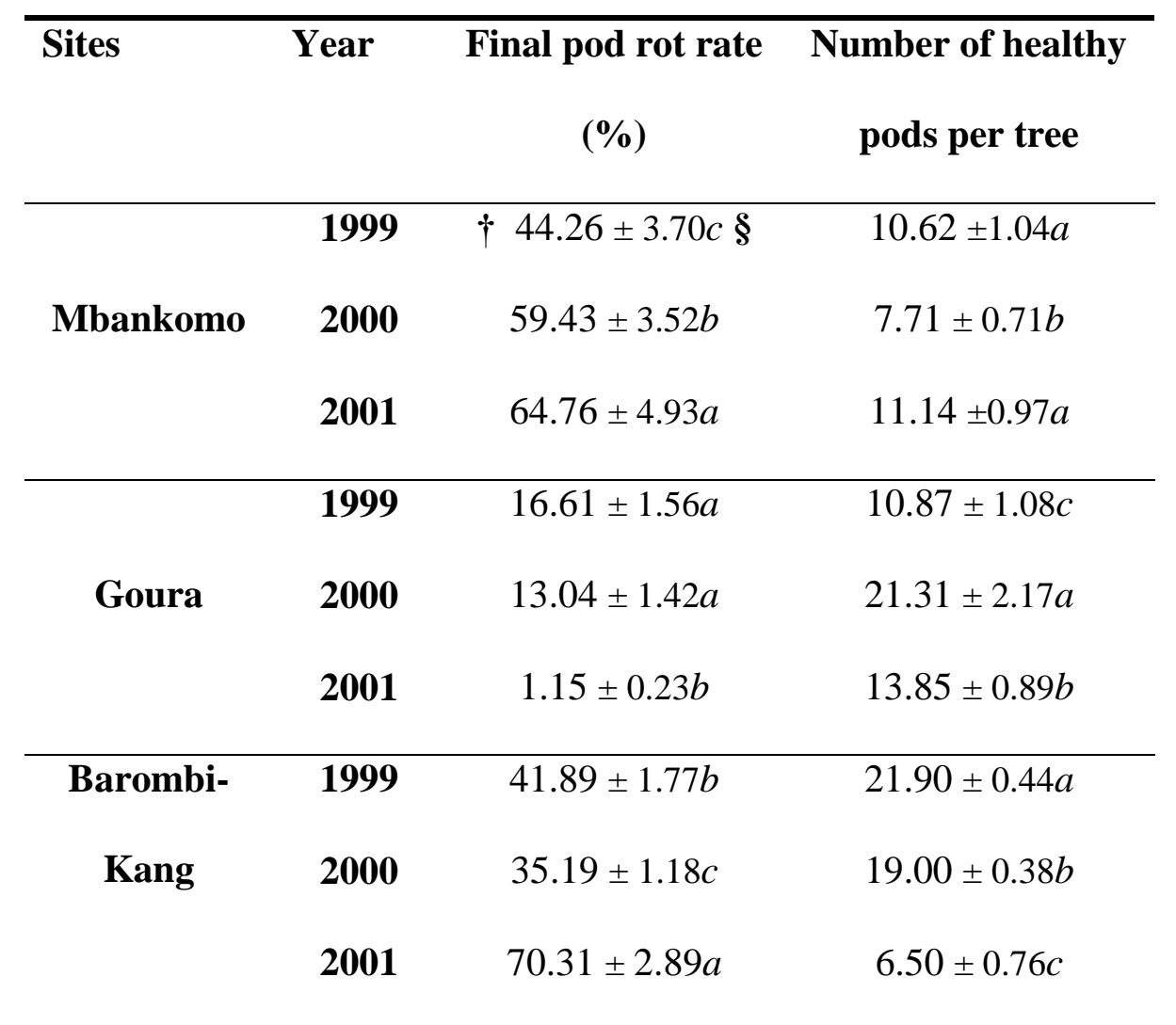

$2 \uparrow$ Means are values \pm standard error

$3 \S$ For each variable at a given site, values followed by the same letter are not significantly different with Newman-Keuls test at $5 \%$ level 
Table 3: Auto-correlations of rainfall at different sites (1999 - 2001)

\begin{tabular}{|c|c|c|c|c|}
\hline Site & Year & Lag (week) & Correlation & $\begin{array}{l}\text { White noise } \\
+\quad \text { (P value) }\end{array}$ \\
\hline \multirow{14}{*}{ Mbankomo } & \multirow{5}{*}{1999} & 1 & 0.07769 & \multirow{5}{*}{0.5880} \\
\hline & & 2 & 0.03813 & \\
\hline & & & & \\
\hline & & 3 & 0.27777 & \\
\hline & & 4 & 0.18834 & \\
\hline & \multirow{4}{*}{2000} & 1 & -0.03364 & \multirow{4}{*}{0.2403} \\
\hline & & 2 & -0.12438 & \\
\hline & & 3 & -017005 & \\
\hline & & 4 & 0.31207 & \\
\hline & \multirow{5}{*}{2001} & 1 & 0.33633 & \multirow{5}{*}{0.4040} \\
\hline & & 2 & 0.20602 & \\
\hline & & & & \\
\hline & & 3 & 0.06774 & \\
\hline & & 4 & 0.10049 & \\
\hline \multirow{12}{*}{ Goura } & \multirow{4}{*}{1999} & 1 & 0.04657 & \multirow{4}{*}{0.8672} \\
\hline & & 2 & -0.02783 & \\
\hline & & 3 & 0.14162 & \\
\hline & & 4 & 0.20364 & \\
\hline & \multirow{5}{*}{2000} & 1 & 0.01838 & \multirow{5}{*}{0.9663} \\
\hline & & 2 & -0.01026 & \\
\hline & & & & \\
\hline & & 3 & 0.07725 & \\
\hline & & 4 & -0.02992 & \\
\hline & \multirow{3}{*}{2001} & 1 & 0.36892 & \multirow{3}{*}{0.5298} \\
\hline & & & & \\
\hline & & 2 & 0.12501 & \\
\hline
\end{tabular}




\begin{tabular}{|c|c|c|c|c|}
\hline & & 3 & 0.03107 & \\
\hline & & 4 & -0.04581 & \\
\hline \multirow{13}{*}{ Barombi- } & \multirow{5}{*}{1999} & 1 & -0.00288 & \multirow{5}{*}{0.6686} \\
\hline & & 2 & -0.26238 & \\
\hline & & & & \\
\hline & & 3 & -0.04436 & \\
\hline & & 4 & -0.02525 & \\
\hline & \multirow{4}{*}{2000} & 1 & -0.00820 & \multirow{4}{*}{0.9907} \\
\hline & & 2 & 0.03259 & \\
\hline & & 3 & -0.05487 & \\
\hline & & 4 & -0.11992 & \\
\hline & \multirow{4}{*}{2001} & 1 & -0.00529 & \multirow{4}{*}{0.8724} \\
\hline & & 2 & 0.13300 & \\
\hline & & 3 & 0.06208 & \\
\hline & & 4 & -0.19185 & \\
\hline
\end{tabular}

$2+$ White noise (P value): non significance of the correlation if $\mathrm{P}-$ Value $>0.05$

3

4

5

6

7

8

9

10

11

12 Please format the tables according to the Canadian Journal of Plant Pathology 
1 Table 4: Auto-correlations of pod rot rate at different sites (1999 - 2001)

\begin{tabular}{|c|c|c|c|c|}
\hline Site & Year & Lag (week) & Correlation & $\begin{array}{c}\text { White noise } \\
\text { (P value) }\end{array}$ \\
\hline \multirow{12}{*}{ Mbankomo } & \multirow{4}{*}{1999} & 1 & 0.38177 & \multirow{4}{*}{0.0007} \\
\hline & & 2 & 0.39539 & \\
\hline & & & 0.49067 & \\
\hline & & 4 & 0.24886 & \\
\hline & \multirow{4}{*}{2000} & 1 & 0.81794 & \multirow{4}{*}{$<0.0001$} \\
\hline & & 2 & 0.68899 & \\
\hline & & 3 & 0.51443 & \\
\hline & & 4 & 0.35122 & \\
\hline & \multirow{4}{*}{2001} & 1 & 0.69931 & \multirow{4}{*}{$<0.0001$} \\
\hline & & 2 & 0.33266 & \\
\hline & & 3 & 0.14526 & \\
\hline & & 4 & -0.07983 & \\
\hline \multirow{12}{*}{ Goura } & \multirow{4}{*}{1999} & 1 & 0.73008 & \multirow{4}{*}{$<0.0001$} \\
\hline & & 2 & 0.52308 & \\
\hline & & 3 & 0.32898 & \\
\hline & & 4 & 0.20190 & \\
\hline & \multirow{5}{*}{2000} & 1 & 0.45732 & \multirow{5}{*}{0.0052} \\
\hline & & 2 & 0.48730 & \\
\hline & & & & \\
\hline & & 3 & 0.34699 & \\
\hline & & 4 & 0.02463 & \\
\hline & \multirow{3}{*}{2001} & 1 & 0.39230 & \multirow{3}{*}{0.0174} \\
\hline & & & & \\
\hline & & 2 & 0.08095 & \\
\hline
\end{tabular}




\begin{tabular}{|c|c|c|c|c|}
\hline & & 3 & -0.31991 & \\
\hline & & 4 & -0.26096 & \\
\hline \multirow{12}{*}{$\begin{array}{c}\text { Barombi- } \\
\text { Kang }\end{array}$} & \multirow{4}{*}{1999} & 1 & 0.61937 & \multirow{4}{*}{0.0005} \\
\hline & & 2 & 0.45014 & \\
\hline & & 3 & 0.23869 & \\
\hline & & 4 & 0.16833 & \\
\hline & \multirow{4}{*}{2000} & 1 & 0.63346 & \multirow{4}{*}{$<0.0001$} \\
\hline & & 2 & 0.57992 & \\
\hline & & 3 & 0.50878 & \\
\hline & & 4 & 0.15422 & \\
\hline & \multirow{4}{*}{2001} & 1 & 0.86274 & \multirow{4}{*}{$<0.0001$} \\
\hline & & 2 & 0.70645 & \\
\hline & & 3 & 0.52839 & \\
\hline & & 4 & 0.27160 & \\
\hline
\end{tabular}

2

3

4

5

6

7

8

9

10

11

12 
Please format the tables according to the Canadian Journal of Plant Pathology

2 Table 5: Regression models between pod rot rate and rainfall regime.

\begin{tabular}{|c|c|c|c|c|}
\hline Site & Year & Equation of the model* & $\mathbf{R}^{2}$ & P-value \\
\hline \multirow{4}{*}{ Mbankomo } & 1999 & $\dagger y=0.168 R A I N$ & $53 \%$ & $<0.001$ \\
\hline & 2000 & $y=0.096 R A I N$ & $56 \%$ & $<0.001$ \\
\hline & 2001 & $y=0.146 R A I N$ & $61 \%$ & $<0.001$ \\
\hline & $1999-2001$ & $y=0.120$ RAIN & $69 \%$ & $<0.001$ \\
\hline \multirow{4}{*}{ Goura } & 1999 & $y=0.150$ RAIN & $62 \%$ & $<0.001$ \\
\hline & 2000 & $y=0.167$ RAIN & $57 \%$ & $<0.001$ \\
\hline & $1999-2000$ & $y=0.146 R A I N$ & $74 \%$ & $<0.001$ \\
\hline & 1999 & $y=0.429 R A I N$ & $68 \%$ & $<0.001$ \\
\hline Barombi- & 2000 & $y=0.210$ RAIN & $54 \%$ & $<0.001$ \\
\hline \multirow[t]{2}{*}{ Kang } & 2001 & $y=0.223 R A I N$ & $58 \%$ & $<0.001$ \\
\hline & $1999-2001$ & $y=0.257$ RAIN & $81 \%$ & $<0.001$ \\
\hline
\end{tabular}

$3 \uparrow y=\operatorname{arcsine} \sqrt{P R R}$, with $P R R=$ Pod Rot Rate, $R A I N=$ Rainfall)

4 
3 Table 6: Rainfall ( $\mathrm{mm}$ ) necessary to start a weekly pod rot rate of $1 \%$ per year in different sites (estimations based on the equations of Table 4)

\begin{tabular}{lcccc}
\hline \multicolumn{1}{c}{ Sites } & \multicolumn{5}{c}{ Year } \\
\cline { 2 - 5 } & 1999 & 2000 & 2001 & $1999-2001$ (mean) \\
\hline Mbankomo & 34.2 & 59.8 & 39.3 & 47.8 \\
Goura & 38.3 & 34.4 & - & 39.3 \\
Barombi-Kang & 13.8 & 27.3 & 25.7 & 22.3 \\
\hline
\end{tabular}

\section{5}

6 
1 Figures Please read the guidelines for ms submission.

2 1. remove the external boxes

32 . Close the graph boxes

$4 \quad 3$. Put legend within the graph boses

54 4. Combine graphs within figures, graph with the same ' $X$ ' axix should combine to save space and to provide more visibility to the data.

7 5. Put the figure captions on a separate pages before the presentation of figures 


\section{$1 \quad$ Figure captions}

2 Figure 1: Evolution of weekly pod rot rate and of daily rainfall at Mbankomo

3 Figure2: Evolution of weekly pod rot rate and of daily rainfall at Goura

4 Figure3: Evolution of weekly pod rot rate and of daily rainfall at Barombi-Kang

5 Figure 4: Cross correlations coefficients of Pod Rot Rate (PRR) - Rainfall, for several lags (in

6 week), at Mbankomo

7 Figure 5: Cross correlations coefficients of Pod Rot Rate (PRR) - Rainfall, for several lags (in

8 week), at Goura

9 Figure 6: Cross correlations coefficients of Pod Rot Rate (PRR) - Rainfall, for several lags (in

10 week) at Barombi-Kang

11

12 


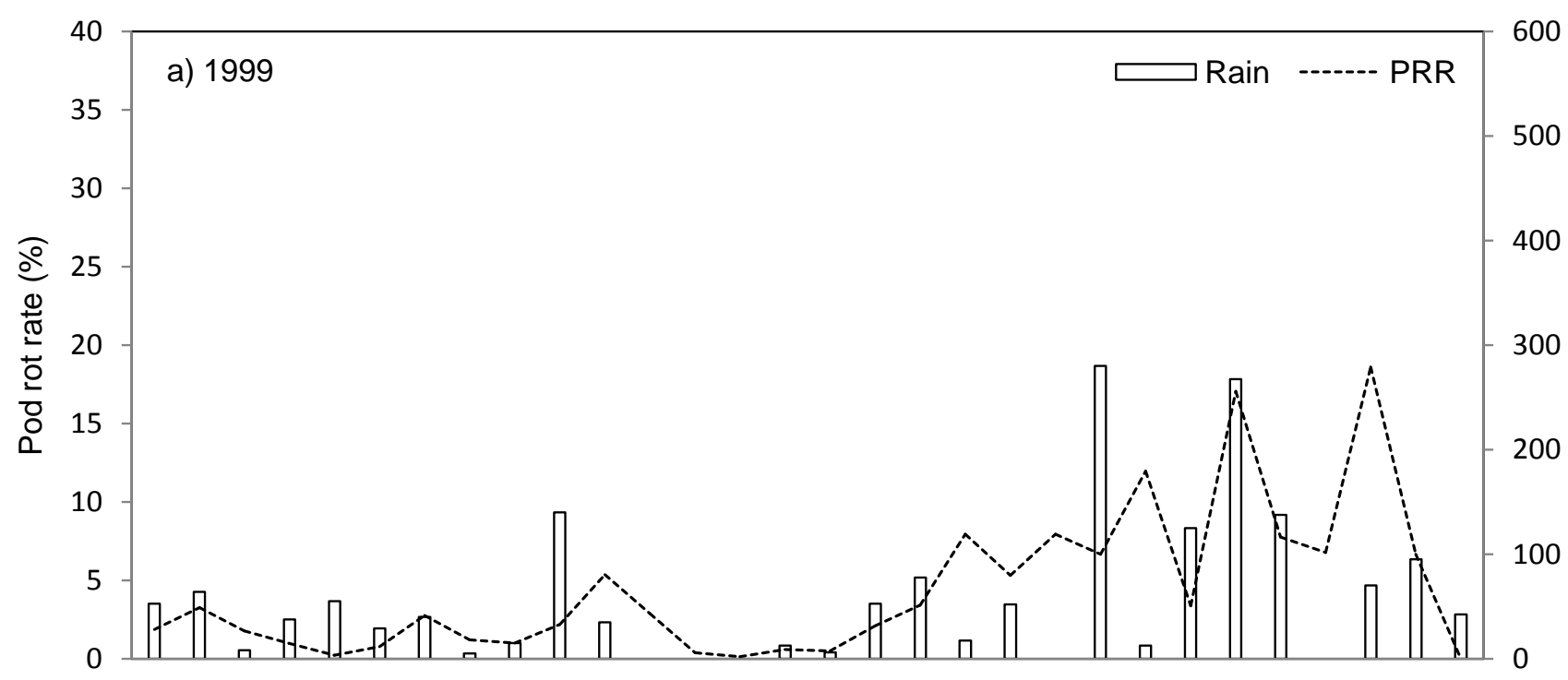

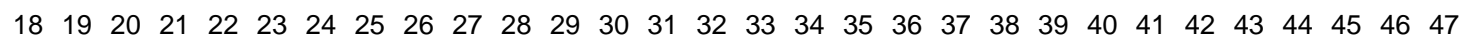

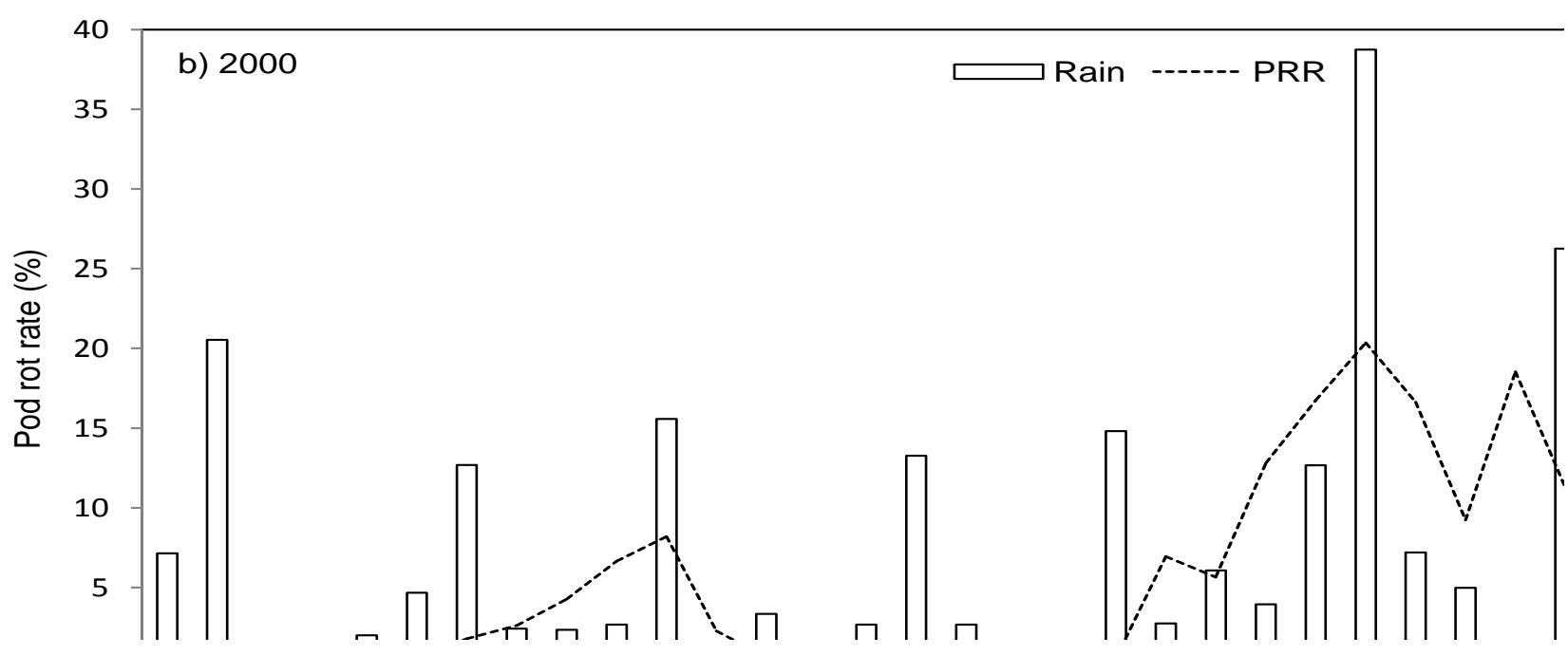

2
3

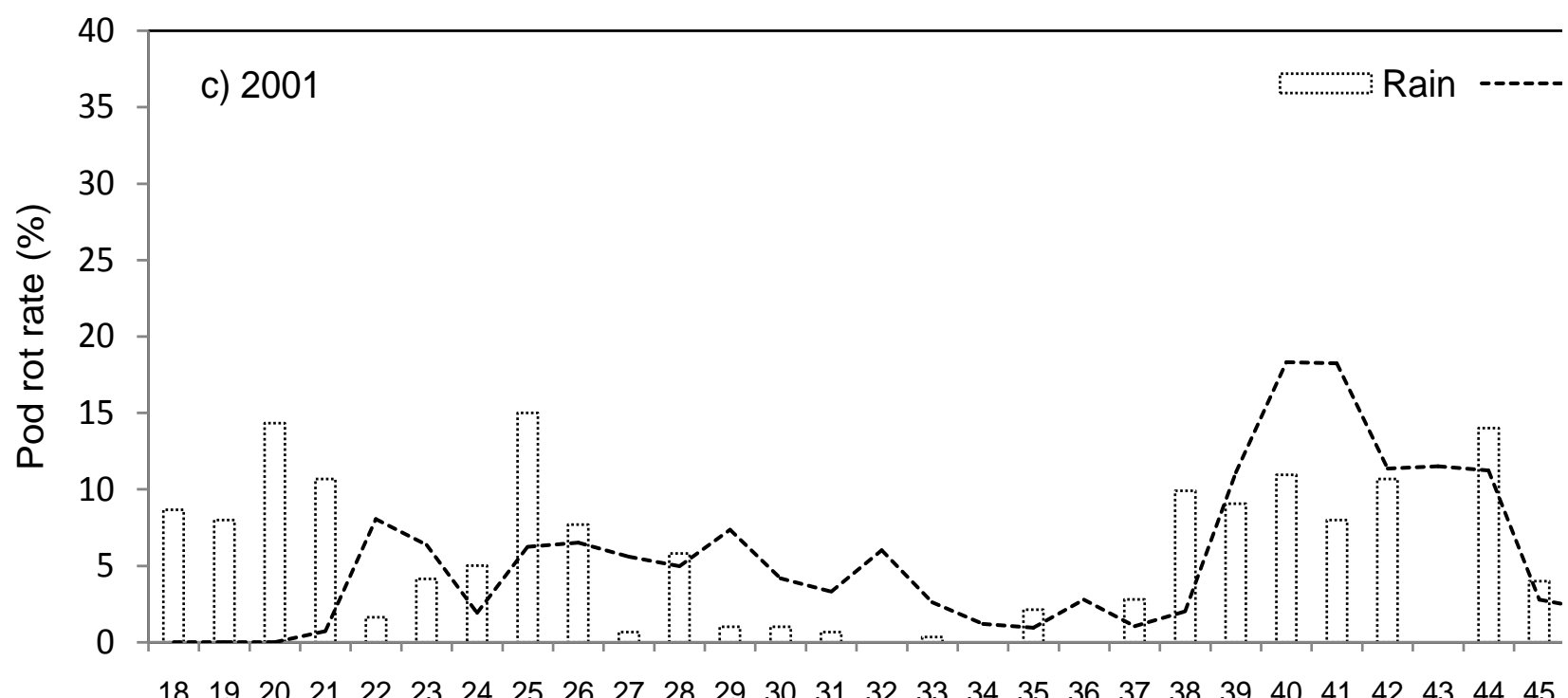



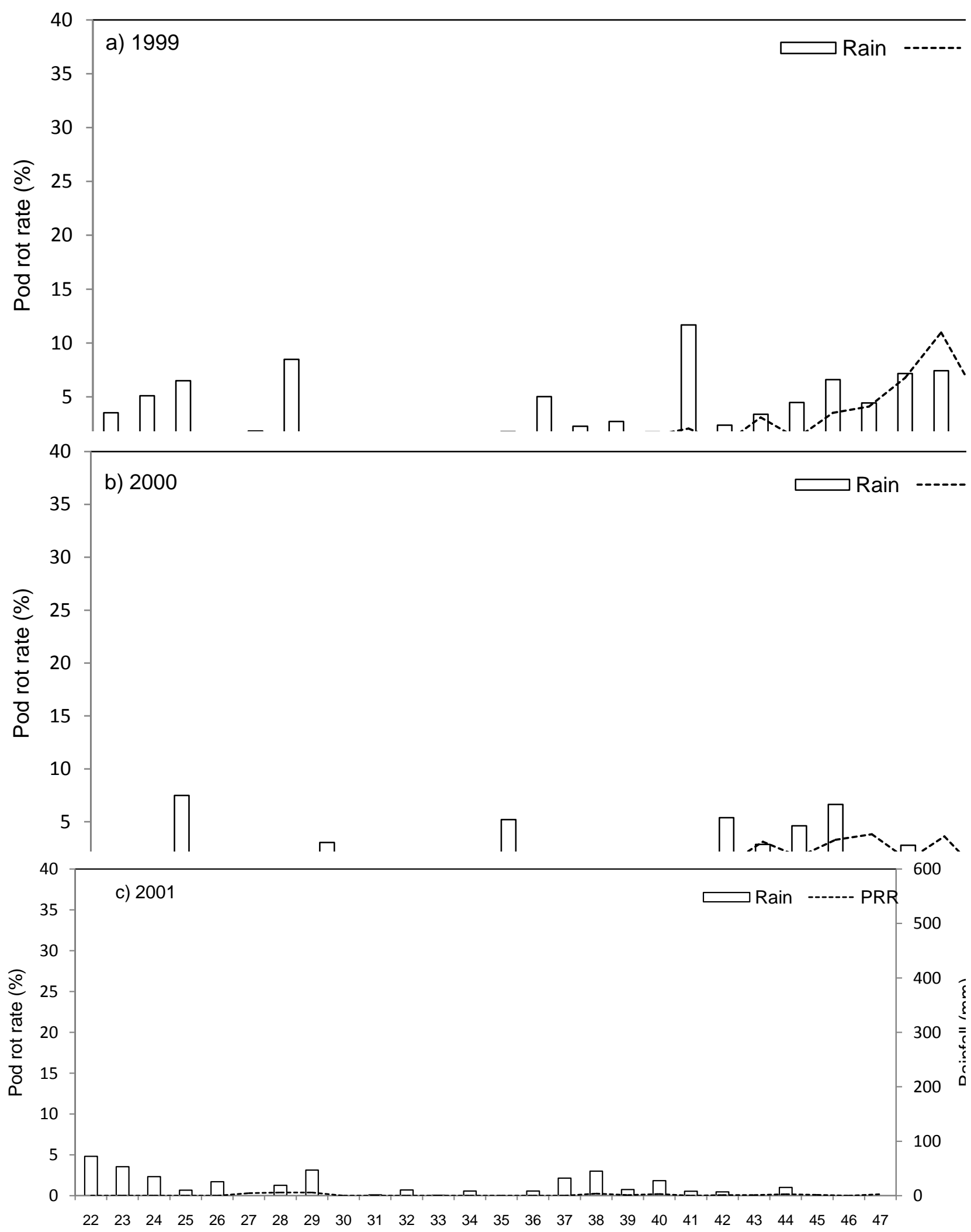

Weeks 

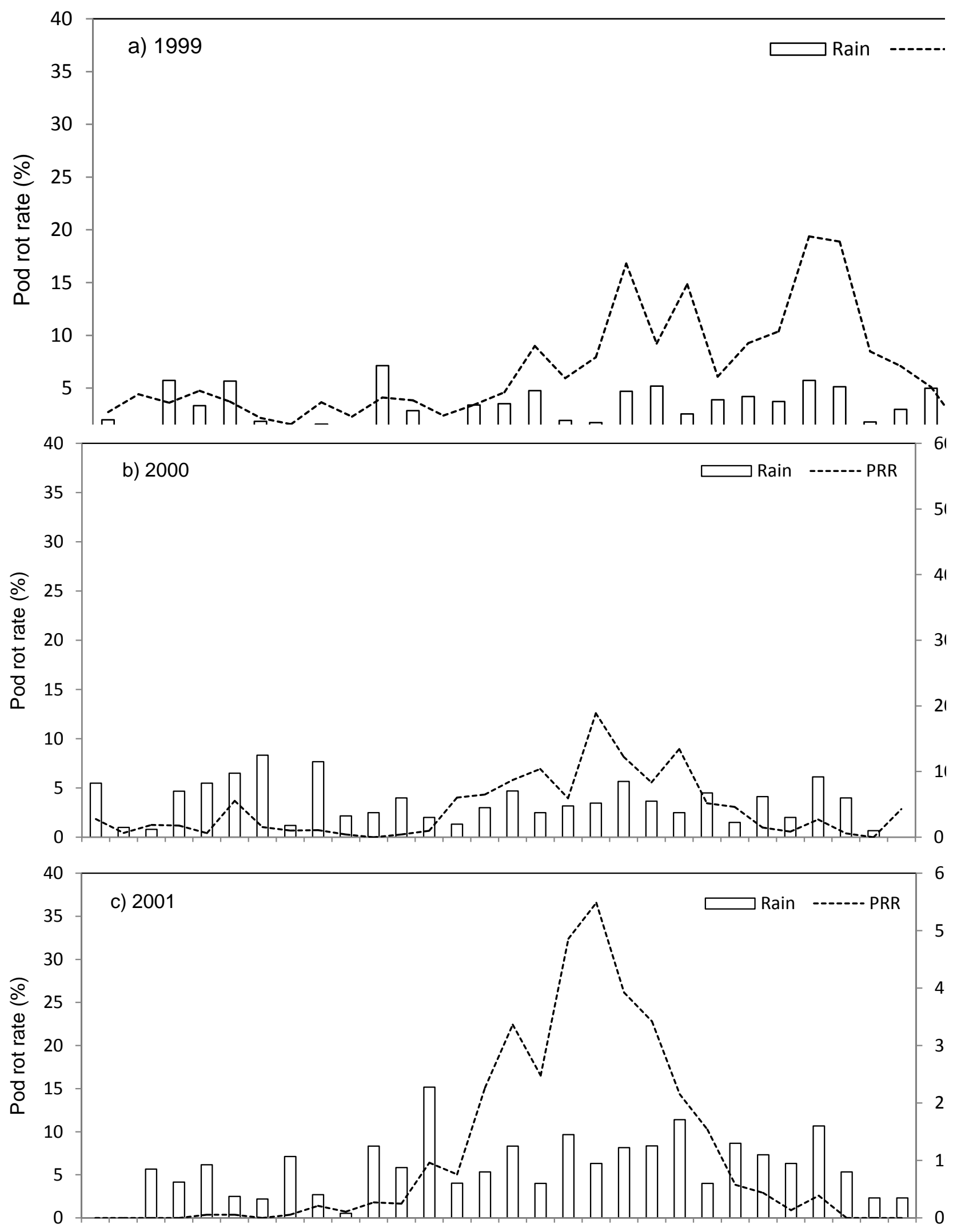

$\begin{array}{llllllllllllllllllllllllllllll}18 & 19 & 20 & 21 & 22 & 23 & 24 & 25 & 26 & 27 & 28 & 29 & 30 & 31 & 32 & 33 & 34 & 35 & 36 & 37 & 38 & 39 & 40 & 41 & 42 & 43 & 44 & 45 & 46 & 47\end{array}$ 


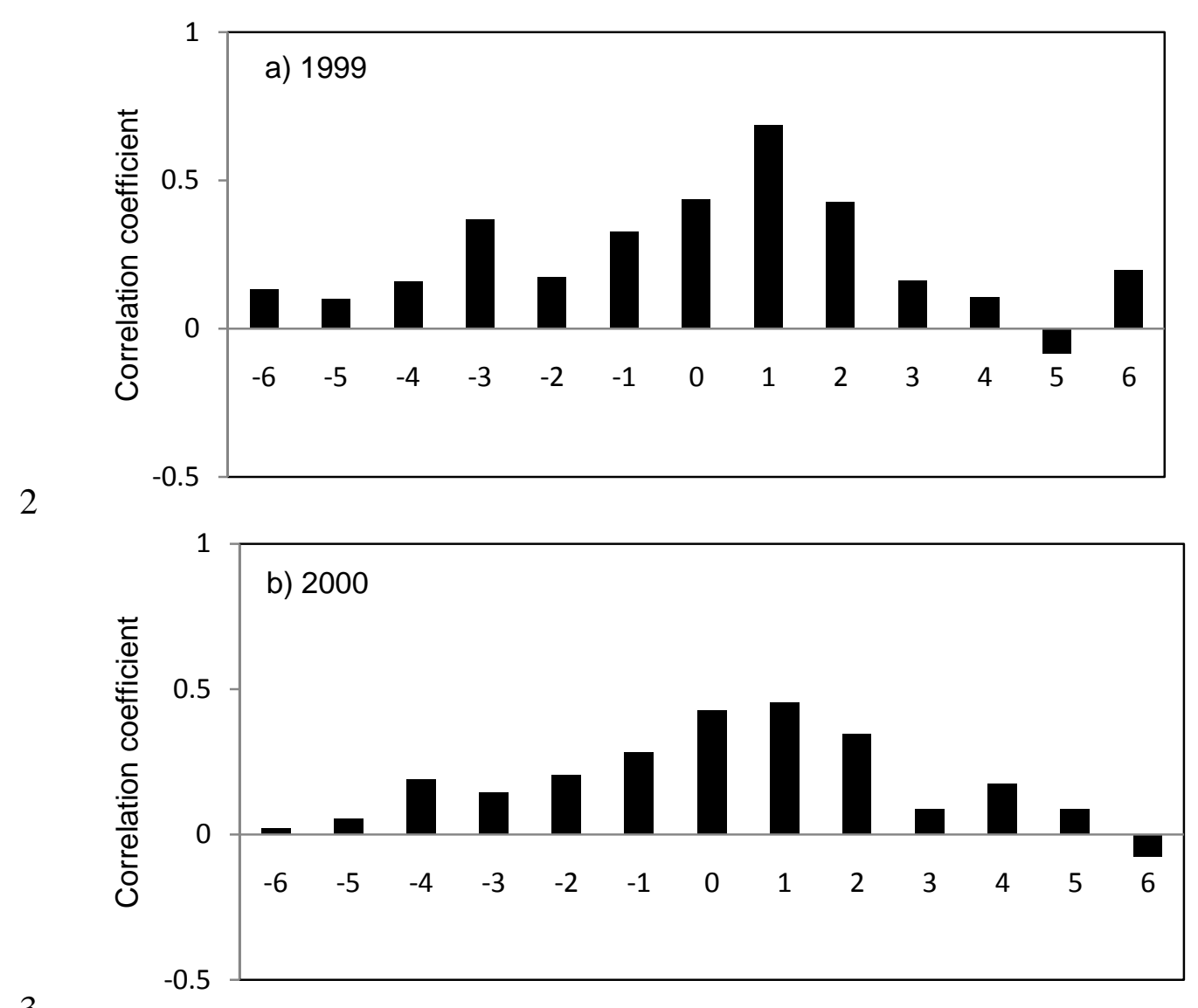

3

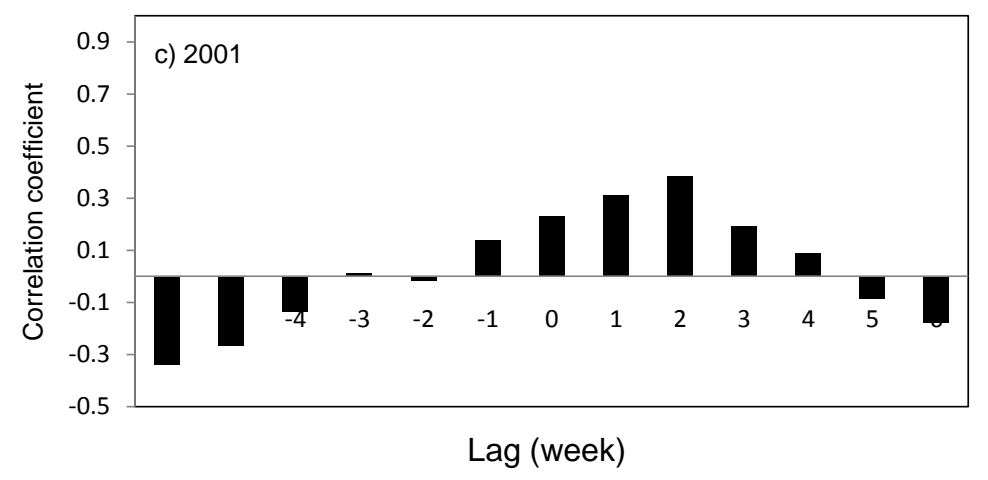

4
5
6
7
8
9 

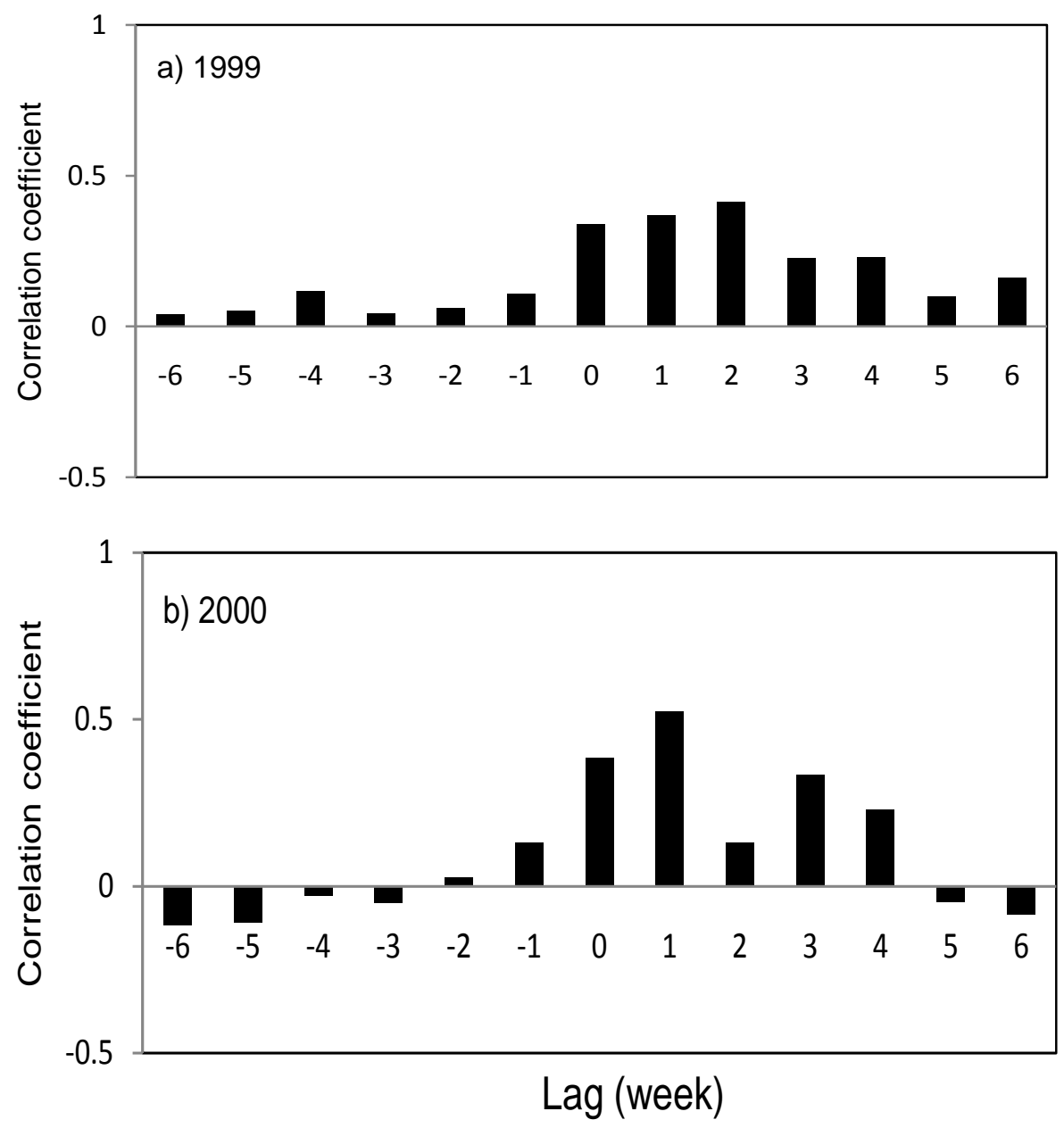

2
3
4
5
6
7
8
9
10
11
12
13
14 

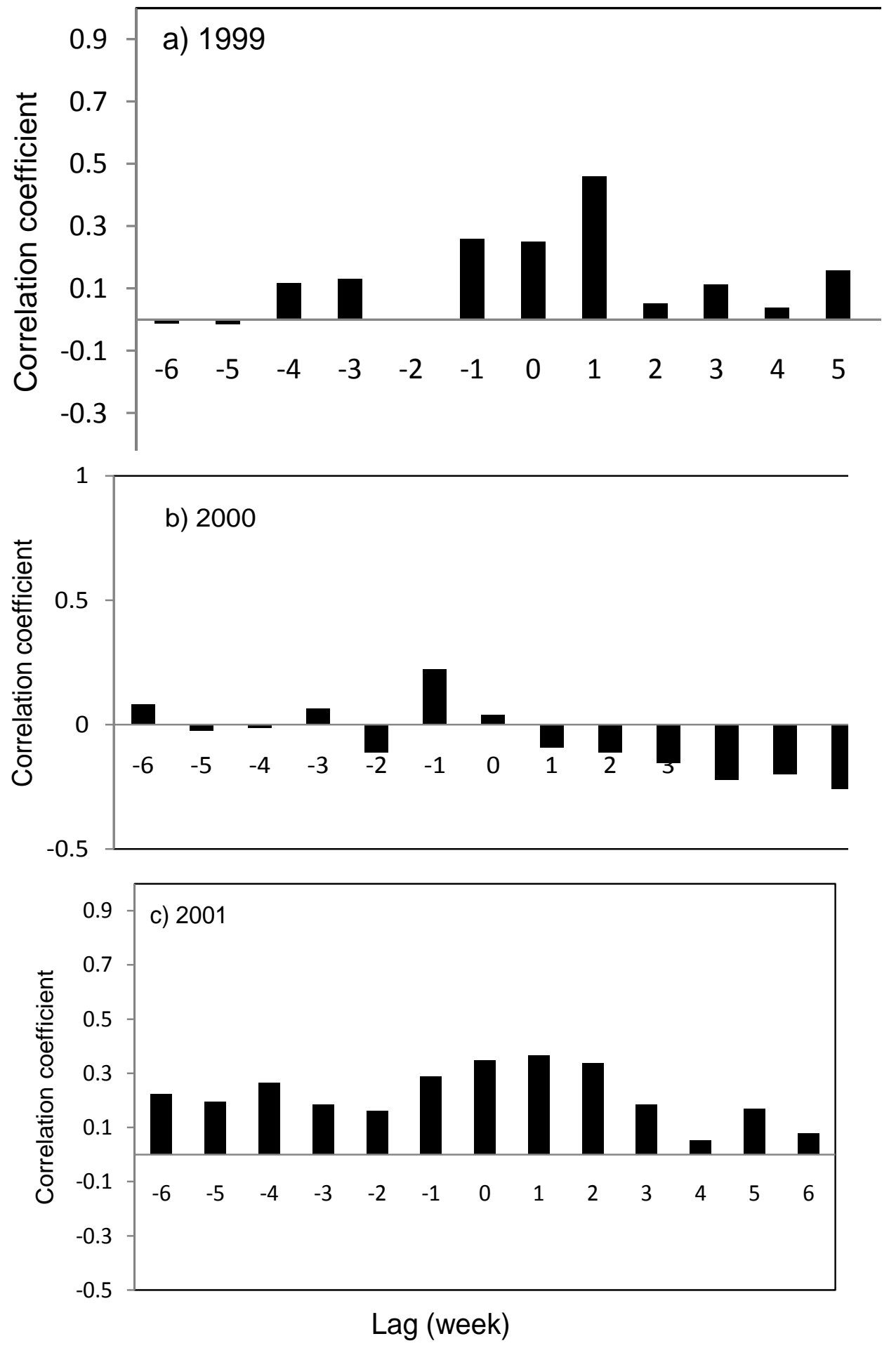

3
4 